\title{
Proses Berpikir Mahasiswa Field Dependent Berdasarkan Kerangka Berpikir Mason
}

\author{
Ika Rahayu Sintiya Dewi ${ }^{1}$, Tjang Daniel Chandra ${ }^{1}$, Hery Susanto ${ }^{1}$ \\ ${ }^{1}$ Pendidikan Matematika-Universitas Negeri Malang
}

\begin{tabular}{l}
\hline INFO ARTIKEL \\
\hline Riwayat Artikel: \\
Diterima: 05-03-2019 \\
Disetujui: 26-07-2019 \\
\hline
\end{tabular}

\section{Kata kunci:}

thought process;

field dependent;

Mason's frame of mind;

proses berpikir;

field dependent;

kerangka berpikir Mason

\begin{abstract}
ABSTRAK
Abstract: The aim of this study is to describe field dependent students' thinking process based on Mason's thinking stcructure. Man and woman field dependent subject used all of aspect exclude introduce aspect in entry phase and why in attack phase. Man subject got stuck ones and he believed that his solution can answer the problem. Women subject get twice stuck and the solution can't answer the problem.

Abstrak: Penelitian ini bertujuan untuk mendeskripsikan proses berpikir mahasiswa field dependent berdasarkan kerangka berpikir matematis Mason. Subjek field dependent laki-laki dan perempuan memenuhi semua aspek kecuali aspek introduce pada fase entry dan why pada fase attack. Perbedaannya yaitu subjek 1 mengalami stuck 1 kali dan percaya bahwa hasil pekrjaannya telah dapat menjawab persoalan dan subjek 2 mengalami 2 kali stuck dan tidak dapat menyelesaikan masalah yang diberikan.
\end{abstract}

\section{Alamat Korespondensi:}

Ika Rahayu Sintiya Dewi

Pendidikan Maematika

Universitas Negeri Malang

Jalan Semarang 5 Malang

E-mail: Ikarsintiyad@gmail.com

Pemecahan masalah sering menjadi topik dalam banyak penelitian baik dalam negeri maupun luar negeri. Khususnya dalam pendidikan matematika, pemecahan masalah sangat penting karena dapat melatih nalar yang dibutuhkan dalam menguasai matematika. Pentingnya pemecahan masalah dalam matematika sehingga menjadi salah satu standar proses menurut NCTM dan pemecahan masalah dapat mengembangkan pemahaman konsep (NCTM, 2000). Soedjadi (Delima, 2017) menyatakan bahwa Indonesia mempunyai dua tujuan utama dalam pendidikan matematika. Pertama, tujuan formil, menekankan pada susunan penalaran dan pengembangan kepribadian anak. Kedua, tujuan materil, menekankan pada pengaplikasian matematika dan kemampuan pemecahan masalah dalam matematika. Pentingnya pemecahan masalah dalam pendidikan matematika tersebut tidak seiring dengan fakta di lapangan. Mahasiswa jurusan Matematika Universitas Negeri Malang masih mengalami kesalahan saat memecahkan masalah permutasi dan kombinasi (Sukoriyanto, Nusantara, Subanji, \& Chandra, 2016). Selain itu, berdasarkan observasi yang dilakukan pada mahasiswa jurusan matematika Universitas Negeri Malang, ditemukan bahwa sebagian besar mahasiswa dapat dengan mudah menyelesaikan soal prosedural dan mengalami banyak kesalahan serta kesulitan ketika dihadapkan dengan soal pemecahan masalah.

Saat memecahkan masalah, terjadi proses berpikir. Ketika mahasiswa mencoba memecahkan masalah dengan melibatkan konsep yang dikuasainya untuk menemukan solusi, disinilah dimulainya proses berpikir (Ersoy \& Guner, 2015). Pentingnya mengetahui cara dan proses berpikir individu dalam memecahkan masalah karena dapat mengidentifikasi kesulitan serta letak kesalahan yang dilakukan selama proses menyelesaikan masalah. Berpikir merupakan proses alami dalam pikiran manusia yang dapat membantu untuk memecahkan berbagai masalah (Sanjaya, Johar, Ikhsan, \& Khairi, 2018). Langkah utama dalam menelusuri proses berpikir yaitu dengan melihat kerangka berpikir saat memecahkan masalah. Kerangka berpikir yang dapat digunakan untuk melihat proses berpikir matematis mahasiswa yaitu salah satunya kerangka berpikir matematis Mason. Selain kerangka berpikir tersebut, tahapan Polya juga dapat dijadikan sebagai dasar untuk mengatahui cara berpikir seseorang. Penggunaan cara berpikir matematis merupakan salah satu dari tujuan pengajaran matematika yang paling penting (Stacey, 2007).

Pentingnya berpikir matematis yaitu dapat mendukung sains, teknologi, kehidupan ekonomi dan pengembangan dalam perekonomian (Delima, 2017). Oleh karena itu, dalam penelitian ini akan digunakan kerangka berpikir matematis menurut Mason. Kerangka berpikir tersebut terdiri dari tiga fase, yaitu fase entry terdapat aspek know, want \& introduce, fase attack terdapat aspek try, maybe, \& why, fase review terdapat aspek check, reflect, \& extend (Mason dkk, 2010). Inti yang ingin dicapai dalam fase entry yaitu memahami masalah secara keseluruhan, fase attack dapat dimulai saat individu telah memahami masalah dan mencoba untuk menemukan solusi dari masalah serta berakhir saat individu telah menyelesaikan masalah, fase review adalah fase yang menekankan pada perluasan, refleksi, serta pengecekan kembali pada hasil pekerjaan saat 
menyelesaikan masalah. Selain itu, proses penting dalam berpikir matematis yaitu terdapat generalizing, specializing, conjecturing, dan convincing. Perbedaan cara berpikir dan menjawab tiap individu salah satunya dipengaruhi oleh cara atau karakteristik seseorang dalam mempersepsikan stimulus dari lingkungan dan mengatur informasi yang diterima atau dimiliki, hal ini disebut dengan gaya kognitif menurut Messick (Guisande, Páramo, Tinajero, \& Almeida, 2007). Sejalan dengan gaya kognitif menurut (Ahmadzade \& Shojae, 2013) bahwa secara konseptual dipandang sebagai karakteristik yang mengacu pada bagaimana informasi diterima dan disusun.

Gaya kognitif menurut Kozhevnikov secara historis yang mengacu pada dimensi psikologis merepresentasikan konsistensi dalam sikap kognitif dan pemrosesan informasi seseorang (Sozcu, 2014). Menurut Hayes \& Allinson, gaya kognitif memengaruhi bagaimana seseorang melihat lingkungan mereka untuk mendapatkan informasi, bagaimana mereka mengatur dan menginterpretasikan informasi tersebut dan bagaimana mereka menggunakan interpretasi tersebut untuk memandunya dalam bertindak (Guisande et al., 2007). Gaya kognitif jika dilihat dari aspek psikologi terbagi menjadi field dependent dan field independent. FDI (field dependent/independet) menggambarkan dua cara berbeda dalam memproses informasi. Field dependence/independence memengaruhi prestasi akademik seseorang. Mahasiswa field independent cenderung berprestasi dalam sains dan field dependent sukses dalam bidang humaniora (Ahmadzade \& Shojae, 2013). Menurut Sozcu (Sozcu, 2014), field dependence- independence mempunyai kontribusi penting pada perilaku kognitif seseorang dan untuk strategi belajar mereka. Khususnya, FI cenderung lebih independent dalam hal pengembangan keterampilan merestruktur kognitif dan kurang independent dalam hal keterampilan komunikasi interpersonal dan metode belajar. Sebaliknya, FD cenderung lebih independent dalam keterampilan komunikasi interpersonal dan kurang independent dalam hal pengembangan restruktur kognitif dan strategi belajar.

Beberapa penelitian sebelumnya telah banyak pembahasan mengenai perbedaan field dependent dan independent serta kemampuan seseorang yang field independent dalam menganalisa masalah, individu field dependent dipandang kurang dalam hal menganalisa masalah dan kemampuan matematisnya. Hal ini sangat menarik untuk membahas bagaimana cara individu field dependent memecahkan masalah secara mandiri karena dalam memecahkan masalah membutuhkan kemampuan analisa yang baik. Hal menarik tersebut yaitu seberapa dalam ketidakmandirian field dependent dalam menyelesaikan masalah dan seburuk apa kemampuan analisanya. Hasil penelitian menunjukkan bahwa perempuan cenderung mempunyai gaya kognitif field dependent dan laki-laki cenderung field independent (Ahmadzade \& Shojae, 2013).

Kecenderungan perempuan dalam mempunyai gaya kognitif field dependent sejalan dengan jarangnya laki-laki mempunyai gaya kognitif field dependent. Menurut penelitian yang dilakukan Zokaei mengungkapkan bahwa perempuan lebih tertarik dalam belajar dan lebih termotivasi memperoleh peringkat akademik (Ahmadzade \& Shojae, 2013). Perempuan yang cenderung mempunyai gaya kognitif field dependent ternyata mempunyai motivasi yang besar dalam belajar dan peringkat akademik, sedangkan utuk laki-laki tidak banyak yang mempunyai gaya kognitif field dependent sehingga sangat menarik apabila ditelusuri bagaimana proses berpikirnya dalam memecahkan masalah matematika.

\section{METODE}

Pendekatan yang digunakan dalam penelitian ini yaitu kualitatif dan jenis penelitian eksploratif karena penelitian ini bertujuan untuk mengeksplor dan mendeskripsikan proses berpikir mahasiswa field dependent dalam memecahkan masalah trigonometri berdasarkan kerangka berpikir Mason. Penelitian kualitatif menurut (Creswell, 2012) menganalisis data dengan deskripsi menggunakan analisis teks dan menafsirkan makna temuan yang lebih luas.

Subjek dalam penelitian ini yaitu mahasiswa tingkat pertama program studi pendidikan matematika yang telah menempuh mata kuliah tentang trigonometri. Pemilihan subjek ditentukan berdasarkan beberapa kriteria dan tahapan (lihat gambar 1). Tes yang digunakan untuk memilih subjek yaitu tes GEFT yang diikuti oleh 60 mahasiswa yang terbagi dalam dua sesi. Sesi pertama dan kedua diikuti oleh 30 mahasiswa. Dari tes tersebut terdapat 11 mahasiswa dengan gaya kognitif field dependent, 10 mahasiswa field intermediate, dan 39 mahasiswa field independent. Kemudian dipilih dua subjek yang bergaya kognitif field dependent yaitu satu subjek perempuan dan satu subjek laki-laki. Sumber data utama dalam penelitian kualitatif yaitu Peneliti (Creswell, 2012) dan sumber pendukung dalam penelitian ini yaitu, tes dan wawancara. Tes yang digunakan yaitu tes GEFT (Group Embedded Figure Test) dan tes pemecahan masalah (TPM).

\section{Group Embedded Figures Test (GEFT)}

Tes ini digunakan untuk mengidentifikasi gaya kognitif field dependent dan field independent (Kepner \& Neimark, 1984). GEFT terdiri atas tiga bagian, dengan jumlah soal 25. Skor pada tes tersebut yaitu 0 jika salah dan 1 jika benar. Bagian pertama terdiri dari 7 Soal tetapi tidak dihitung dalam skor karena hanya sebagai latihan. Bagian kedua terdapat 9 soal dan bagian ketiga terdiri dari 9 soal. Tes ini digunakan karena non-verbal dan hanya membutuhkan keterampilan bahasa yang minimum untuk melakukan tes ini dan sifat psikometrik pada instrumen tersebut telah diteliti dalam berbagai latar lintas budaya dan diterima dengan layak (Altun \& Cakan, 2006). 


\section{Tes Pemecahan Masalah}

Tes ini merupakan tes untuk mengetahui proses berpikir mahasiswa. Soal pada tes ini termasuk dalam kategori masalah matematika karena tidak dapat diselesaikan langsung secara prosedural dan membutuhkan analisa yang lebih mendalam. Masalah pada tes ini merupakan masalah trigonometri.

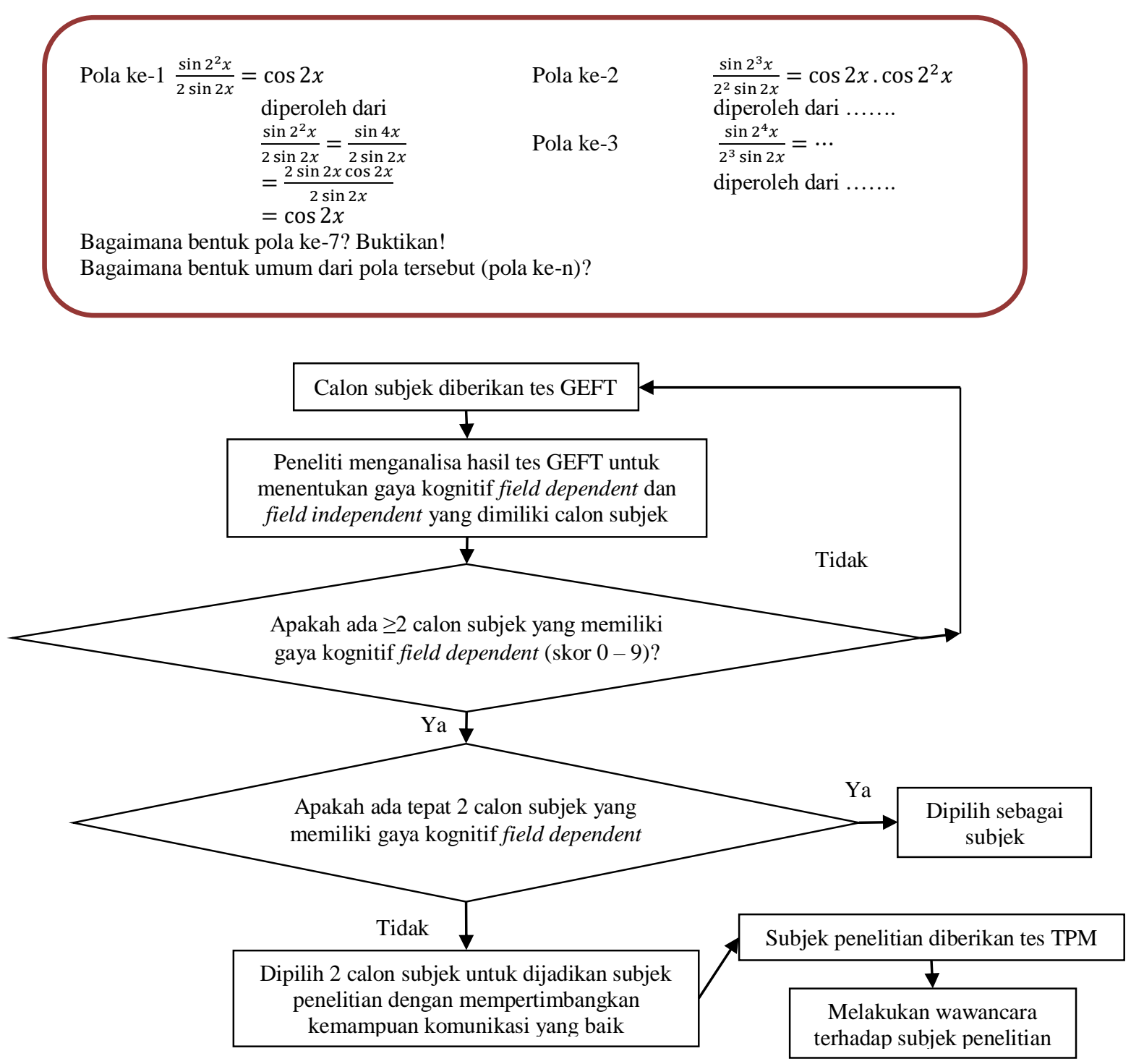

\section{Gambar 1. Alur Proses Pelaksanaan Penelitian}

\section{HASIL}

Berdasarkan hasil pekerjaan mahasiswa dalam menyelesaikan masalah trigonometri yang akan dibahas yaitu proses berpikir matematis mahasiswa berdasarkan kerangka berpikir Mason. Proses berpikir matematis tersebut didapat dari data tertulis hasil pekerjaan mahasiswa serta data wawancara pada subjek terpilih. Tes GEFT diikuti oleh 27 mahasiswa laki-laki dan 33 mahasiswa perempuan. Terdapat 7 mahasiswa laki-laki dan 4 mahasiswa perempuan yang mempunyai gaya kognitif field dependent. Calon subjek yang terpilih yaitu 1 subjek laki-laki yang mempunyai gaya kognitif field dependent (S1) dan 1 perempuan (S2).

\section{Proses Berpikir Matematis S1 dalam Menyelesaikan Masalah}

Proses berpikir S1 dalam menyelesaikan masalah tersebut hanya memenuhi sebagian aspek dalam fase-fase pada kerangka berpikir Mason. Selain itu, S1 tidak berhasil menyelesaikan masalah dengan baik dan benar. Hasil akhir yang didapatkan tidak dapat menjawab pertanyaan dalam masalah yang diberikan. S1 mengawali dengan memahami masalah. 
S1 memahami masalah dengan membaca soal secara seksama. Pada saat memahami masalah, S1 juga berusaha mendapatkan hubungan dari pola-pola yang diberikan. Fase entry dilakukan oleh S1 meskipun tidak sempurna. S1 dapat menyebutkan informasi yang ada disoal dengan baik artinya S1 telah melaksanakan aspek know. Ketika S1 ditanya mengenai informasi yang berhubungan yang dapat membantu menyelesaikan masalah, S1 menjelaskan hubungan antar pola yang ada. Pada awalnya S1 hanya menjelaskan hubungan antar pola bagian pembilang di ruas kiri saja, kemudian S1 menjelaskan hubungan pola ruas kanan setelah ditanyakan. Hubungan antar pola yang dijelaskan tersebut hanya secara singkat dan tidak detail. Berikut hasil wawancara dengan S1.

$\mathrm{P}: \quad$ informasi yang lainnya selain yang sudah jelas dituliskan disini apa?

S1: $\quad$ pola pertama itu $\sin 2^{2} x$ pola kedua $\sin 2^{3} x$, pola ketiganya $\sin 2^{4} x$. Nah dari situ saya tahu bahwa nanti pola keempatnya $\sin 2^{5} x$ dan selanjutnya.

$\mathrm{P}: \quad$ itu kan yang ruas kirinya saja, bagaimana dengan ruas kanan ?

$\mathrm{S1} \quad \quad$ pola pertamanya kan sudah diketahui $\cos 2 x$, pola keduanya $\cos 2 x \cdot \cos 2^{2} x$ selanjutnya pola ketiganya aka nada hubungannya dengan hal tersebut seperti misal pangkatnya tambah naik jadi $\cos 2^{3} x$.

Aspek want juga dilaksanakan dengan baik, terlihat ketika wawancara S1 menyebutkan tujuan dari soal dengan baik dan lengkap. Menurut S1, dengan adanya pola ke-1, ke-2 dan ke-3 dapat membantu dan menuntunnya dalam menemukan dan menyelesaikan pola ke-7 dan pola ke-n. Meskipun telah melaksanakan aspek know dan want tetapi S1 tidak melaksanakan aspek introduce. Berikut hasil wawancara dengan S1.

$\mathrm{P}$ : apa tujuan dalam soal? termasuk yang ditanyakan.

S1: yang ditanyakan itu pola kedua, pola ketiga, pola ketujuh, pola ke-n. sebenarnya hal ini juga menuntun, pola ke-1, ke-2, ke-3 kemudian lompat ke pola ke-7 dan akhirnya ditanya pola ke-n jadi menurut saya hal ini dapat menuntun dan membantu dalam menyelesaikan soal dengan benar. Sebenarnya sampai pola ke-2 sudah paham polanya.

Masalah tidak dapat diselesaikan tanpa pemahaman terhadap masalah tersebut (Ersoy \& Guner, 2015). Oleh karena itu, fase attack dimulai setelah S1 memahami masalah atau telah melaksanakan fase entry. S1 memulai dari pola ke-2. Pada pola ke2 tersebut, S1 melakukan pengecekan kebenaran atau pembuktian pada dugaan yang telah diberikan. Terlihat pada gambar 2 bahwa S1 masih mencoba untuk menguraikan $\sin 2 x$ dan $\cos (x+x)$ sebagai dasar untuk pembuktiannya. Ternyata S1 tidak menggunakan penguraian $\cos (x+x)$ dalam pembuktiannya dan hanya menggunakan penguraian $\sin 2 x$. Pemilihan cara penyelesaian tersebut benar akan tetapi ada kesalahan pada langkah ke-3 yaitu S1 hanya menuliskan pembilangnya saja tanpa penyebutnya, tetapi langkah seterusnya S1 kembali menuliskannya dengan lengkap. Uraian pembuktian tersebut termasuk dalam aspek maybe. Berikut hasil pekerjaan S1.

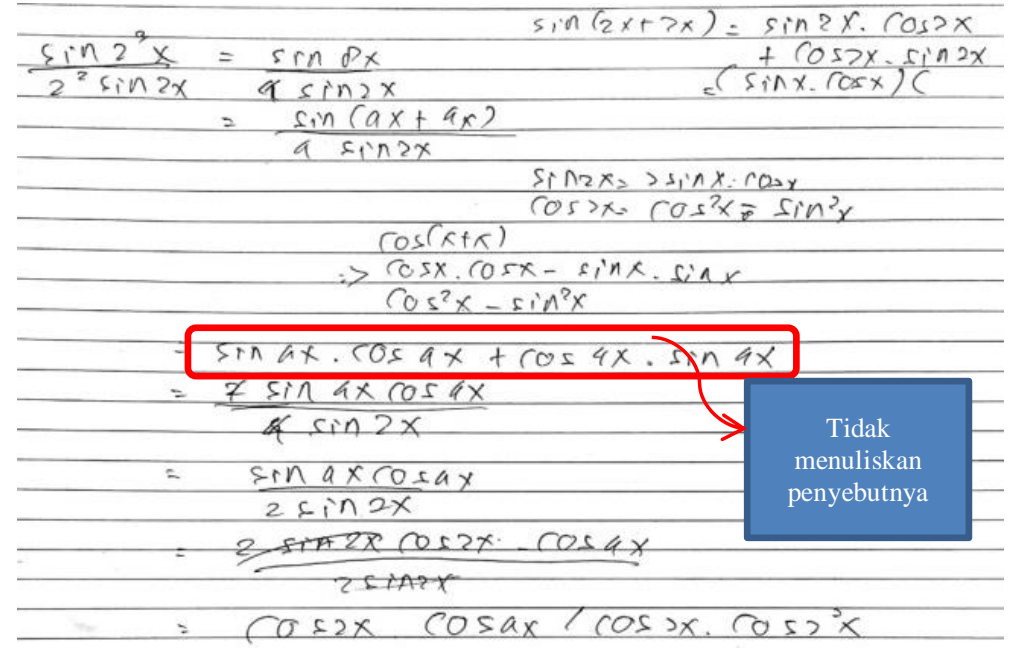

\section{Gambar 2. Hasil Pekerjaan S1 dalam Membuktian Pola ke-2}

Setelah melakukan aspek maybe, S1 melanjutkan dengan aspek try yaitu dengan membuat dugaan pada pola ke-3. Dalam membuat dugaan pada pola ke-3, S1 melihat keteraturan serta hubungan dari pola ke-1 dan ke-2 kemudian membuktikannya dengan melihat ide kunci pada pola sebelumnya. Pada pola ke-2 maupun ke-3, S1 tidak melakukan aspek why artinya S1 tidak dapat menunjukkan alasan pada tiap langkah yang ditulisnya. Namun, pada pola ke-3 tersebut S1 melakukan conjecturing dan convincing. 
S1 menyelesaikan pola ke-3 dengan baik dan tidak ada kesalahan. Berbeda dengan pola ke-2 yang masih menimbang cara yang akan digunakan. Dugaan sementara yang dibuat oleh S1 terbukti benar. S1 membuktikannya dengan menguraikan ruas kiri yang akhirnya sama dengan ruas kanan. Setelah pola ke-3 S1 melanjutkan dengan pola ke-7 yang ide kuncinya sama seperti yang digunakan pada pola ke-3 tetapi pada awalnya S1 salah dalam membuat dugaan sementara. S1 membuat pola ke-7 hanya ruas kanan saja yaitu hanya menuliskan $\cos 2 x \cdot \cos ^{2} 2 x \cdot \cos ^{3} 2 x \ldots \cdot \cos ^{7} 2 x$. Kesalahan tersebut berkaitan dengan pernyataan saat S1 menjelaskan mengenai prediksi pola yaitu menjelaskan secara terpisah antara ruas kanan dan ruas kiri. Hal ini mengindikasikan bahwa S1 tidak melaksanakan fase entry dengan baik. S1 menyadari kesalahannya pada dugaan sementara pola ke-7 saat S1 mencoba menyelesaikan pola ke-n. Sesuai dengan hasil wawancara berikut.

$\mathrm{P}$ : sebenarnya pola yang ditanyakan disini ruas kiri saja, ruas kanan saja atau semuanya?

S1: awalnya saya mengira sebelah kanan saja seperti awal saya tulis di pola ke-7 dan ke-n. setelah itu waktu sampai soal pola ken saya baru menyadari bahwa ruas kirinya juga harus disertakan.

Pada hasil wawancara terlihat bahwa S1 melakukan aspek reflect yaitu dengan memperbaiki konjektur yang telah dibuatnya sehingga menjadi konjektur baru yang siap untuk dibuktikan kembali. Tidak ada ide baru dalam pembuktian pola ke7, S1 cenderung mengikuti ide pada pola sebelumnya. Pada beberapa langkah pembuktian tersebut terdapat kesalahan dan langkah yang tidak lengkap. Kesalahan pada pembuktian tersebut yaitu kesalahan karena tidak teliti yaitu cos $124 x$. sin $124 x$ yang seharusnya $\cos 128 x \cdot \sin 128 x$. Langkah yang tidak lengkap dalam pembuktian tersebut yaitu pada langkah 5 (lihat Gambar 3), S1 menuliskan $\sin 128 x=2^{6} \cdot \sin 2 x \cdot \cos 2 x \cdot \cos 4 x \cdot \cos 8 x \ldots \cdot \cos 64 x$ tanpa diketahui langkah penyelesaiannya ruas kiri sama dengan ruas kanan, S1 tidak menyertakan alasan saat menuliskan pernyataan tersebut. Kemudian diakhir penyelesaian pola ke-7 dengan singkat $\mathrm{S} 1$ menuliskan $\cos 2 x \cdot \cos ^{2} 2 x \cdot \cos ^{3} 2 x \ldots \cos ^{7} 2 x$ dan juga tidak menyertakan alasan pula. Berikut hasil pekerjaan S1 pada pola ke-7.

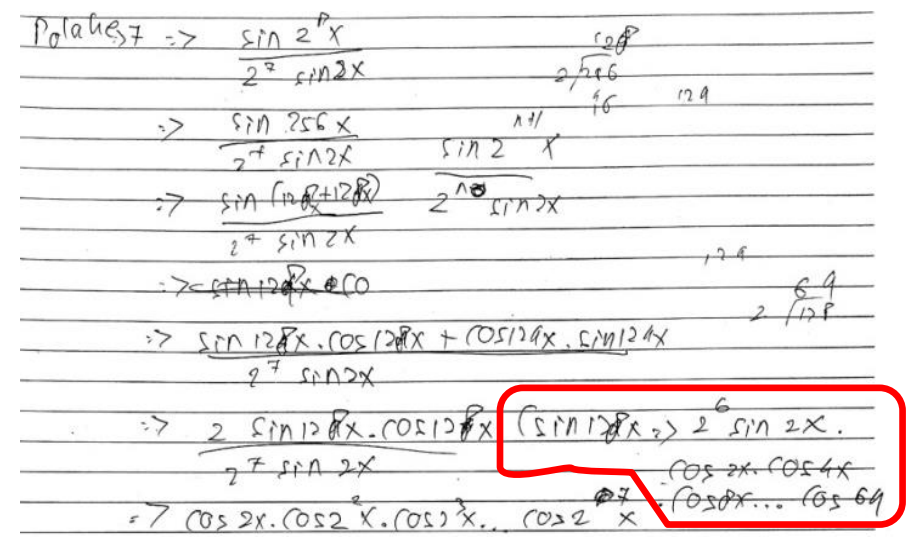

\section{Gambar 3. Hasil Pekerjaan S1 dalam Menduga dan Membuktikan Pola Ke-7}

Pada pola ke-7 tersebut S1 hanya melakukan aspek try dan maybe tetapi tidak melakukan aspek why. Proses pembuatan dugaan awal juga memperlihatkan bahwa S1 juga melaksanakan conjecturing serta convincing dalam pembuktiannya meskipun terjadi beberapa kesalahan. Kemudian S1 beralih pada pola ke-n, yaitu kembali melakukan conjecturing. Berikut dugaan awal yang dibuat oleh S1 sebelum diperbaiki.

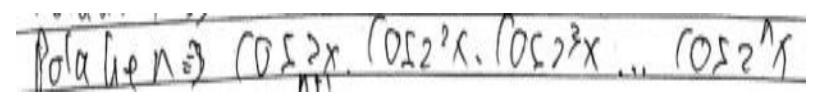

\section{Gambar 4. Hasil Pekerjaan S1 dalam Membuat Dugaan Pada Pola Ke-n}

Terlihat pada gambar 4 bahwa kesalahan membuat konjektur sama seperti kesalahan pada pola ke-7 yaitu hanya menuliskan satu ruas saja. Kemudian S1 kembali memperbaiki konjektur setelah S1 menyadari kesalahannya. Konjektur baru yang dibuatnya pada pola ke-n benar. S1 membuktikan konjektur tersebut dengan induksi matematis. Pada bagian $n=k+1$, S1 tidak dapat menyelesaikan pembuktian dan cenderung tidak berhubungan antar langkah yang ditulisnya. Pada akhir penyelesaian, S1 hanya menuliskan "konstanta 2 dan $2^{2}$ " yang tidak berhubungan dengan pernyataan sebelumnya. Berikut hasil pekerjaan S1 dalam menyelesaikan pola ke-n. 


$\Rightarrow n=a+1 \rightarrow \frac{\sin 2^{4+2} x}{2^{4+1} \sin 2 x}=\frac{\sin 2^{k} \cdot 2^{2} x}{2 \cdot 2^{4} \sin 2 x} \cdot \frac{\sqrt{\sin 2^{2}-2^{2} x}}{2 \cdot 2^{4} \sin 2 x}$
Gonstanta $2 \operatorname{don} 2^{2}+$

\section{Gambar 5. Hasil Pekerjaan S1 dalam Memperbaiki Dugaan dan Membuktikan Pola Ke-n}

Setelah menyelesaikan masalah hingga pola ke-n, S1 juga melakukan fase review. S1 memeriksa kembali langkahlangkah penyelesaian yang telah ditulisnya dan ide utama dalam menyelesaikan masalah. Akan tetapi, S1 masih tidak dapat melakukan aspek check dengan baik karena meskipun terjadi kesalahan dan penyelesaian tidak sampai akhir S1 masih merasa bahwa hasil pekerjaannya tersebut tidak ada kekurangan. Selain melakukan aspek check dan reflect, S1 juga melakukan aspek extend yaitu dengan membuat generalisasi dari pola tersebut. Berikut kerangka berpikir S1 dalam menyelesaikan masalah berdasarkan kerangka berpikir matematis Mason.

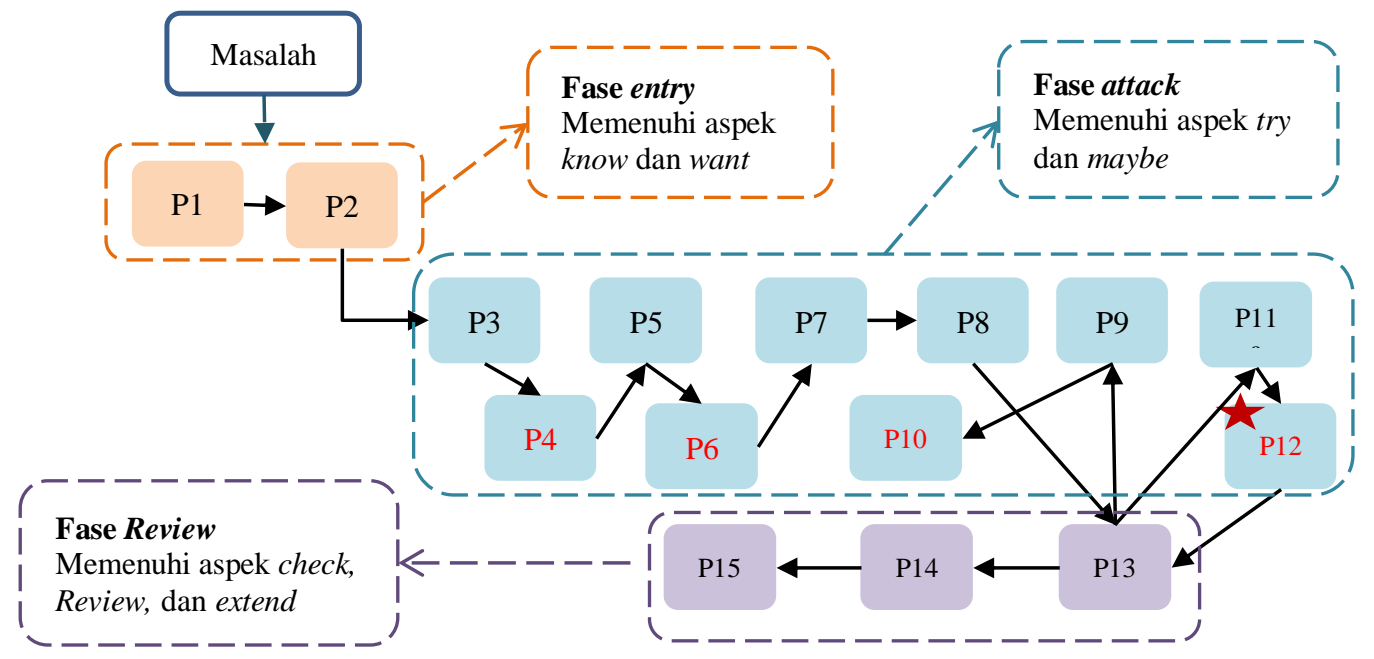

Gambar 6. Kerangka Berpikir Matematis S1 dalam Memecahkan Masalah

Tabel 1. Deskripsi Pengodean Kerangka Berpikir Matematis S1

\begin{tabular}{cl}
\hline Kode & \multicolumn{1}{c}{ Keterangan } \\
\hline P1 & Diketahui pola pertama beserta pembuktiannya, pola ke-2 tanpa pembuktian \\
P2 & Ditanya Pola ke-2, ke-3, ke-7 dan ke-n \\
P3 & Memilih rencana membuktikan pola ke-2 dengan cara menguraikan kedua ruas atau salah satu ruas saja \\
P4 & Membuktikan pola ke-2 \\
P5 & Membuat konjektur pola ke-3 yaitu $\frac{\sin 2^{4} x}{2^{3} \sin 2 x}=\cos 2 x \cdot \cos 2^{2} x \cdot \cos 2^{3} x$ \\
P6 & Membuktikan konjektur pola ke-3 \\
P7 & Membuat konjektur pola ke-7 yaitu $\cos 2 x \cdot \cos 2^{2} x \cdot \cos 2^{3} x \ldots \cdot \cos 2^{7} x$ \\
P8 & Membuat konjektur pola ke-n yaitu $\cos 2 x \cdot \cos 2^{2} x \cdot \cos 2^{3} x \ldots \cdot \cos 2^{n} x$ \\
P9 & Memperbaiki konjektur pola ke-7 yaitu $\cos 2 x \cdot \cos 2^{2} x \ldots \cdot \cos 2^{7} x=\frac{\sin 2^{8} x}{2^{7} \sin 2 x}$ \\
P10 & Membuktikan konjektur pola ke-7 \\
P11 & Memperbaiki konjektur pola ke-n yaitu $\cos 2 x \cdot \cos 2^{2} x \ldots \cdot \cos 2^{n} x=\frac{\sin 2^{n+1} x}{2^{n} \sin 2 x}$ \\
P12 & Membuktikan konjektur pola ke-n \\
P13 & Memeriksa ide utama pada penyelesaian masalah \\
P14 & Memeriksa tiap langkah penyelesaian \\
P15 & Membuat generalisasi dari pola yang diketahui \\
\hline
\end{tabular}

\section{Proses Berpikir Matematis $\mathbf{S} 2$ dalam Menyelesaikan Masalah}

Secara keseluruhan, S2 masih belum dapat menyelesaikan masalah dengan baik. Beberapa kesalahan yang terjadi saat menyelesaikan masalah diantaranya kesalahan disebabkan oleh tidak menguasai konsep dan juga tidak dapat memahami masalah dengan baik. Dalam proses penyelesaiannya S2 telah melakukan hampir semua aspek kecuali aspek why dan introduce meskipun tidak sempurna. 
S2 mengawali dengan membaca soal secara seksama. S2 telah melakukan fase introduce, aspek know dilakukan dengan menyatakan informasi yang diketahui dalam soal dengan lengkap. Akan tetapi, S2 tidak dapat menyebutkan informasi diluar soal. Kemudian S2 melanjutkan dengan aspek want yaitu menjelesakan tujuan soal serta rencana penyelesaian yang akan digunakannya untuk menyelesaikan masalah. Ketika S2 ditanya mengenai rencana penyelesaian, S2 menjelaskan cara penyelesaian pola ke-3. Menurut S2, tujuan masalah atau pertanyaan dalam maslaah yang diberikan hanya mencari dan membuktikan bentuk umum atau pola ke-n saja. Berikut hasil wawancara dengan S2.

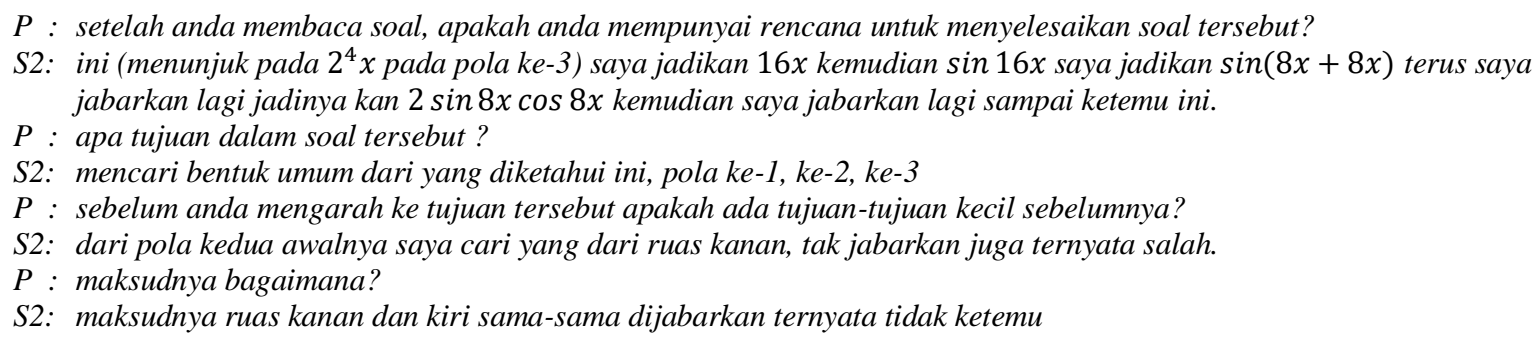

S2 melanjutkan dengan mencoba menyelesaikan masalah setelah melakukan fase entry atau pekerjaan untuk memahami masalah. Langkah awal dalam penyelesaian masalah yaitu diawali dengan mencoba membuktikan pola ke-2. Dalam pembuktian tersebut, S2 masih mencoba menguraikan kedua ruas. S2 masih belum mempunyai keyakinan dalam memilih cara penyelesaian tersebut. Kemudian S2 memutuskan untuk menguraikan ruas kiri yang pada akhirnya akan sama dengan ruas kanan. Dalam pemilihan cara penyelesaian tersebut, S2 telah melakukan aspek try sekaligus aspek maybe dalam fase attack.

Penyelesaian pola ke-3 tidak seperti pola ke-2, pada pola ke-3 S2 telah yakin dalam memilih cara penyelesaian yang efektif. Ide utama dalam menyelesaikan pola ke-3 mirip dengan pola sebelumnya. S2 mengawali dengan menguraikan ruas kiri yang diketahui terlebih dahulu karena S2 masih kurang yakin dengan pola yang dimaksud. Setelah menguraikan seperti pola sebelumnya, S2 menemukan hasil pada ruas kanan. Berikut hasil penyelesaian S2 untuk pola ke-3,

$P$ : pada pola ke-3 ini anda menuliskan atau menebak polanya terlebih dahulu atau bagaimana?

S2: tidak mbak, saya memakai cara sebelumnya dulu sampai ketemu ini (menunjuk pada ruas kanan pola ke-3)

$P$ : mengapa anda tidak menebak terlebih dahulu?

S2: karena saya masih kurang yakin dengan polanya, karena ini hanya ada pola ke-1 dan ke-2. Setelah saya mendapatkan pola ke3 baru saya yakin.

Berbeda dengan pola ke-2 dan ke-3 sebelumnya, pada pola ke-7 S2 mengawali dengan membuat dugaan awal terlebih dahulu. Dugaan awal tersebut diperoleh dari pola-pola sebelumnya. Kemudian S2 berusaha membuktikan hasil konjektur yang telah dibuatnya. Hal ini membuktikan bahwa S2 telah melakukan conjecturing dan convincing. Pembuktian pada pola ke-7 menduplikasi ide utama pada pola-pola sebelumnya. Dalam pekerjaan S2 dalam membuktikan pola ke-7 tersebut tidak ada kesalahan. Berikut hasil wawancara dengan S2,

$P$ : pada pola ke-7 dan pola ke-n kan anda menduga terlebh dahulu kemudian membuktikan, dari mana anda mendapatkan dugaan tersebut?

S2: ini kan pada pola ke-1 $2^{2}$ jadi langsung kepikiran bahwa nanti jika pola ke-n akan berbentuk $2^{n+1}$ terus pola ke-2 kan $2^{3}$ ya, jadi dugaan saya benar bahwa pada pola ke-n seperti itu bentuknya. Kemudian yang bawahnya ini (menunjuk pada penyebut di ruas kiri dari pola ke-1) kan ini 2 tidak ada apa-apanya berarti $2^{1}$, kemudian pada pola ke-2 $2^{2}$, pada pola ke-3 $2^{3}$ jadi saya asumsikan $2^{n}$.

Langkah berikutnya yang dilakukan oleh S2 yaitu berusaha membuat dugaan awal untuk pola ke-n, seperti terlihat pada gambar 7 bahwa S2 masih salah dalam membuat konjektur. Konjektur yang dibuat hanya menampilkan ruas kiri saja. Kesalahan ini mirip dengan kesalahan yang dialami oleh S1 yaitu hanya menuliskan satu ruas saja. Perbedaannya yaitu S1 lebih cepat dalam menyadari kesalahannya sedangkan S2 masih lambat. S2 berusaha membuktikan konjektur tersebut. Berikut hasil pekerjaan S2 pada pola ke-n. 


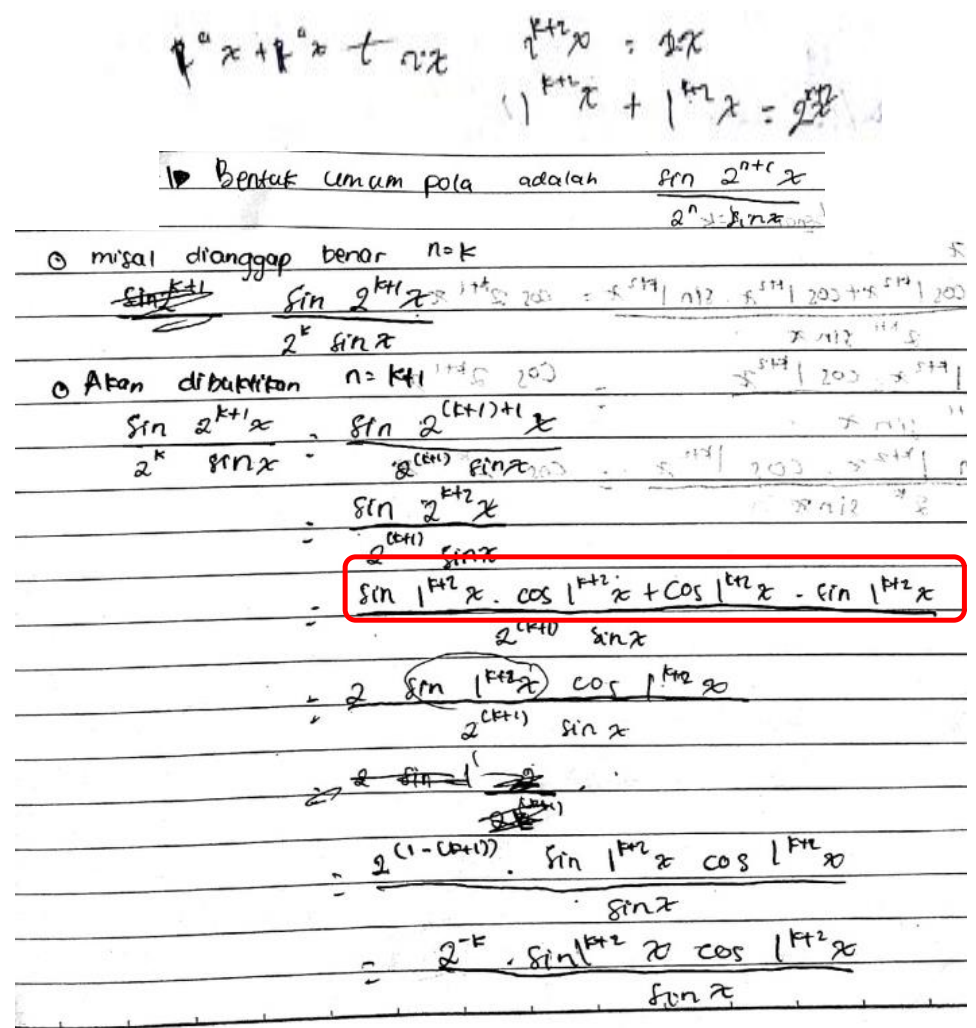

\section{Gambar 7. Hasil Pekerjaan S2 dalam Membuktikan Pola ke-n}

Dari Gambar 7 terlihat bahwa S2 berusaha membuktikan pola ke-n dengan menggunakan induksi matematis. Saat membuktikan untuk $n=1$ tidak ada masalah tetapi ketika $n=k$ dan akan membuktikan untuk $n=k+1$ S2 tetap hanya melibatkan satu ruas saja sehingga S2 merasa kesulitan dalam membuktikan kebenarannya. Selain kesalahan pada konjektur yang dipaksakan untuk dibuktikan kebenarannya, dalam gambar 7 juga terlihat pemahaman S2 mengenai eksponen yang kurang tepat. Pada bagian atas gambar 7 tersebut S2 menuliskan bahwa $1^{k+2} x+1^{k+2} x=2^{k+2} x$. Kesalahan ini memengaruhi pada langkah ke-3 saat akan membuktikan kebenaran untuk $n=k+1$. Pada gambar tersebut terlihat S2 mengklaim bahwa $\sin 2^{k+2} x=\sin 1^{k+2} x \cdot \cos 1^{k+2} x+\cos 1^{k+2} x \cdot \sin 1^{k+2} x$. Saat S2 sampai pada langkah ke-6 pembuktian untuk $n=k+1, \mathrm{~S} 2$ mengalami stuck dan tidak dapat mengatasinya. Berikut hasil wawancara dengan S2,

$P$ : bagaimana anda meyakinkan bahwa dugaan yang anda buat tersebut benar?

S2: untuk yang pola ke-7 ini saya tulis ulang ruas kirinya kemudian dengan menggunakan cara sebelumnya saya jabarkan dan ternyata sama hasilnya. Untuk pola ke-n tersebut saya menggunakan induksi matematika, ini kan diketahui $\frac{\sin 2^{n+1} x}{2^{n} \sin 2 x}=$ $\cos 2 x \cdot \cos 2^{2} x \ldots . \cos 2^{n} x$. terus misal benar ini untuk $n=1$ ini kan jadinya $\frac{\sin 2^{1+1} x}{2^{1} \sin x}=\cos 2 x$, oh iya ini yang bawah salah seharusnya $2^{1} \sin 2 x$ terus $2^{2}$ kan sama dengan 4 jadi saya jadikan $2 . \sin 2 x \cdot \cos 2 x$ kemudian $\sin 2 x$ nya dicoret jadi satu jadi benar untuk $n=1$. Terus misal benar untuk $n=k$ jadi $\frac{\sin 2^{k+1} x}{2^{k} \sin 2 x}=\cos k x$ terus akan dibuktikan benar untuk $n=k+$ 1 kemudian ini buntu sampai disini mbak.

$P$ : kesulitan anda tersebut bagaimana? Dalam hal apa?

S2: ini tadi kesulitannya, menjadikan ini ( menunjuk pada langkah ke-8 pada hasil selesaiannya) sin $2 x$. Yang ternyata jadi $\sin 1 x$

S2 menyadari kesalahan pada konjektur yang telah dibuat sebelumnya, kemudian S2 membuat konjektur baru yang menurutnya lebih baik. Sama seperti ide sebelumnya, S2 berusaha membuktikan pola ke-n dengan menggunakan induksi matematis. Konjektur yang telah diperbaiki tersebut benar tetapi dalam proses pembuktiannya tidak sama dengan konjektur yang telah ditulisnya. S2 telah melakukan aspek try dengan baik pada pola ke-n tersebut yang didalamnya terdapat proses conjecturing. Pada kenyataannya S2 tidak mampu melakukan aspek maybe dengan baik. Berikut hasil pekerjaan S2 pada pola ke-n. 


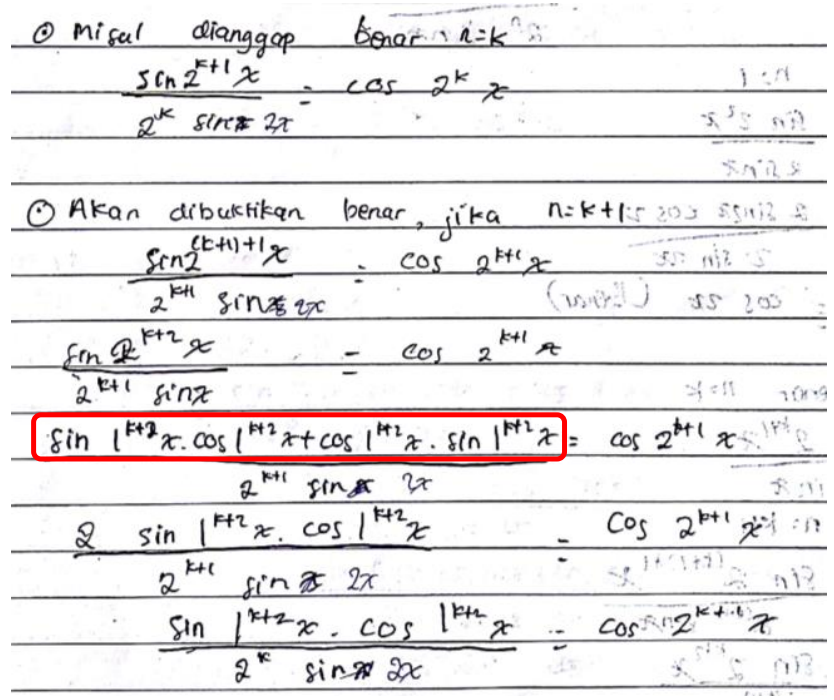

\section{Gambar 8. Hasil Pekerjaan S2 dalam Membuktikan Pola ke-n}

Pada gambar 8, terlihat ada beberapa kesalahan dan ada kesalahan yang terulang dari kesalahan sebelumnya. Langkah pertama pada penyelesaian tersebut yaitu S2 menuliskan "misal benar $n=1$ " yang artinya untuk $n=1$ diasumsikan benar tetapi S2 masih membuktikan kebenaran dari $n=1$. Kemudian ketika melangkah pada asumsi benar untuk $n=k$, S2 salah dalam membuat pernyataan. S2 menuliskan bahwa $\frac{\sin 2^{k+1} x}{2^{k} \sin 2 x}=\cos 2^{k} x \quad$ seharusnya $\frac{\sin 2^{k+1} x}{2^{k} \sin 2 x}=$ $\cos 2 x \cdot \cos 2^{2} x \cdot \cos 2^{3} x \ldots \cdot \cos 2^{k} x$. Kesalahan tersebut terbawa hingga ketika S2 membuktikan untuk $n=k+1$, kemudian pada langkah ketiga kesalahan sebelumnya terulang kembali. S2 menganggap bahwa $2^{k+2} x=1^{k+2} x+1^{k+2} x$ sehingga masih terjadi kesalahan yang sama. Terlihat pada Gambar 8 bahwa S2 tidak dapat menyelesaikan pembuktian tersebut hingga akhir. Seperti pada pembuktian konjektur sebelumnya, S2 kembali tidak dapat mengatasi stuck yang terjadi meskipun S2 telah melakukan aspek reflect. Selain itu, S2 telah melakukan aspek check yaitu memeriksa kembali tiap langkah yang telah ditulisnya. Tetapi S2 tidak melakukan dengan baik karena beberapa kesalahan terjadi berulang kali. Berikut kerangka berpikir S2 dalam memecahkan masalah.

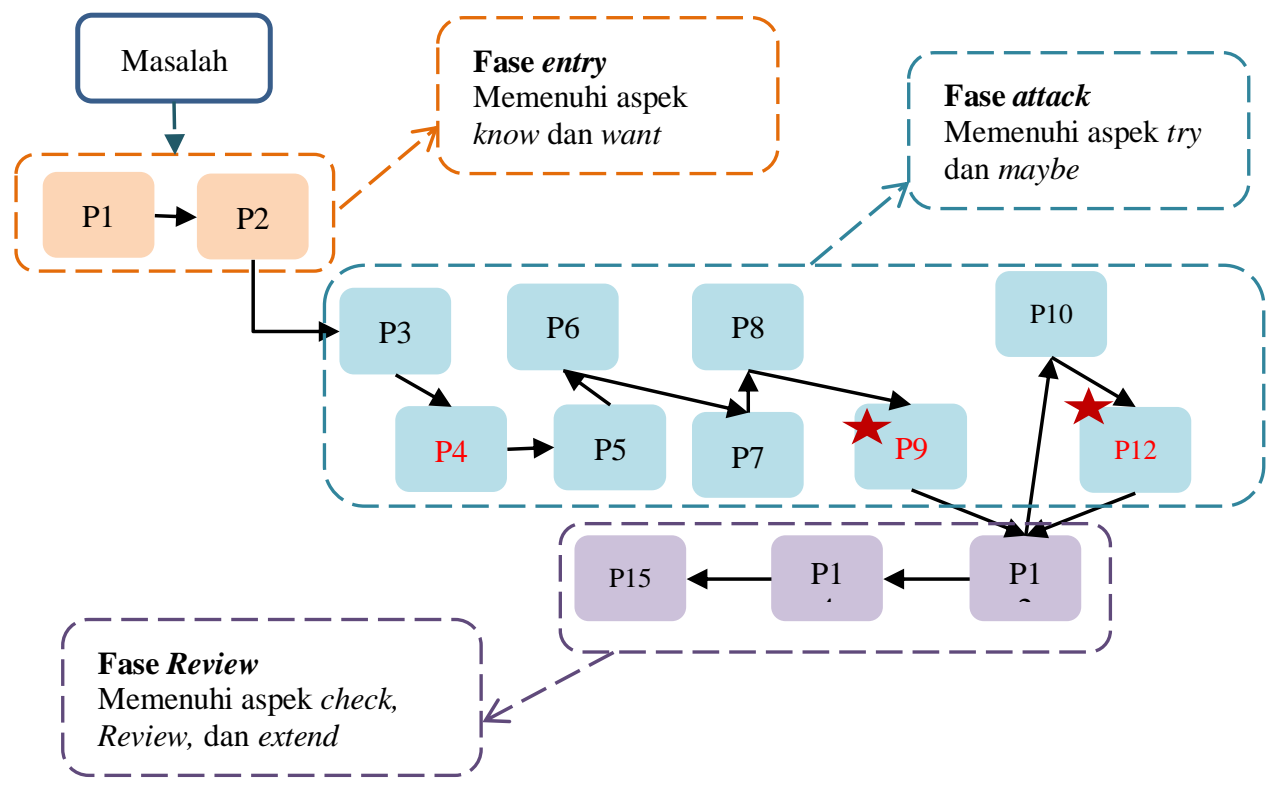

Gambar 9. Kerangka Berpikir Matematis S2 dalam Memecahkan Masalah 
Tabel 2. Deskripsi Pengodean Kerangka Berpikir Matematis S2

\begin{tabular}{cl}
\hline Kode & \multicolumn{1}{c}{ Keterangan } \\
\hline P1 & Diketahui pola ke-1, pola ke-2, pola ke-3, tetapi yang pola ke-3 tidak lengkap \\
P2 & Ditanya mencari pola umum dari pola yang ada \\
P3 & Memilih rencana membuktikan pola ke-2 dengan cara menguraikan kedua ruas atau salah satu ruas saja \\
P4 & Membuktikan pola ke-2 \\
P5 & Menduplikasi cara pola ke-2 yaitu menjabarkan ruas yang diketahui pada pola ke-3 sehingga diperoleh ruas yang lain. \\
P6 & Membuat konjektur pola ke-7 yaitu $\frac{\sin 2^{8} x}{2^{7} \sin 2 x}=\cos 2 x \cdot \cos 2^{2} x \cdot \cos 2^{3} x \ldots \cdot \cos 2^{7} x$ \\
P7 & Membuktikan konjektur pola ke-7 \\
P8 & Membuat konjektur pola ke-n yaitu $\frac{\sin 2^{n+1} x}{2^{n} \sin 2 x}$ \\
P9 & Membuktikan konjektur pola ke-n \\
P10 & Memperbaiki konjektur pola ke-n yaitu $\cos 2 x \cdot \cos 2^{2} x \ldots \cdot \cos 2^{n} x=\frac{\sin 2^{n+1} x}{2^{n} \sin 2 x}$ \\
P11 & Membuktikan konjektur pola ke-n yang baru \\
P12 & Memeriksa ide utama pada penyelesaian masalah \\
P13 & Memeriksa tiap langkah penyelesaian \\
P14 & Membuat generalisasi dari pola yang diketahui \\
\hline
\end{tabular}

\section{PEMBAHASAN}

Kedua subjek mempunyai gaya kognitif field dependent, dikarenakan mempunyai gaya kognitif yang sama, proses penyelesaian masalahnyapun banyak kesamaan. Begitu pula dengan proses berpikir matematisnya mempunyai garis besar kerangka berpikir yang sama. Kedua subjek tidak dapat menyelesaikan masalah dengan baik, hal ini sesuai dengan karakteristik field dependent yang kurang mampu dalam penyelesaian masalah matematis (Azari, Radmehr, Mohajer, \& Alamolhodaei, 2013). Meskipun telah melakukan fase review yang didalamnya terdapat aspek check, reflect, dan extend, tetapi kesalahan masih terjadi pada kedua subjek. Hal ini sejalan dengan hasil penelitian (Mohammad, 2017) bahwa field dependent tidak dapat melakukan pengecekan kembali dalam memecahkan masalah. Artinya subjek field dependent kurang mampu dalam memeriksa kembali hasil pekerjaannya dan tidak dapat merefleksi dengan baik.

Meskipun kedua subjek mempunyai banyak kesamaan dalam penyelesaian masalah, tetapi ada beberapa perbedaan. Perbedaan tersebut yaitu dalam melakukan kesalahan pada proses penyelesaiannya. Subjek perempuan melakukan kesalahan yang sama dua kali saat proses menyelesaikan masalah meskipun telah melakukan aspek check dan reflect. Subjek laki-laki juga melakukan kesalahan tetapi tidak melakukan kesalahan yang sama. Selain itu, keduanya mengalami stuck perbedaannya yaitu subjek perempuan mengalami dua kali stuck dan subjek laki-laki hanya sekali. Dari dua hal terebut terlihat bahwa subjek lakilaki lebih baik dalam proses penyelesaian masalah, hal ini sesuai dengan pendapat Naurzalina dkk (Naurzalina, Karimova, Sarkulov, Tolegenova, \& Zholamanova, Almurzayeva, 2015) bahwa sebenarnya laki-laki cenderung merepresentasikan gaya kognitif field independent dimana field independent lebih mampu dalam menganalisa masalah dan lebih mampu dalam matematika. Menurut Wechsler (Wechsler, 2009) pada usia 17-24 tahun perempuan cenderung lebih logis daripada laki-laki, tetapi hal ini kurang sesuai dengan hasil penelitian. Pada hasil penelitian ditemukan bahwa baik subjek perempuan maupun lakilaki tidak dapat membuat alasan logis pada tiap langkah dalam memecahkan masalah.

\section{SIMPULAN}

Berdasarkan hasil dan pembahasan dari proses berpikir matematis mahasiswa field dependent maka dapat disimpulkan bahwa secara garis besar tidak ada perbedaan yang signifikan dalam proses berpikir matematis subjek perempuan dan laki-laki. Hampir semua aspek dalam tiga fase berpikir matematis dilakukan oleh kedua subjek, tetapi tidak maksimal dalam melakukannya. Terbukti pada hasil penyelesaian kedua subjek tersebut tidak dapat menjawab pertanyaan. Subjek field dependent laki-laki secara garis besar melakukan aspek know dan want dalam fase entry, aspek try dan maybe pada fase attack dan aspek check, reflect, dan extend dalam fase review. Dalam melakukan fase entry atau memahami masalah, S1 telah melakukan dengan cukup baik. Dalam mengidentifikasi pola, S1 tidak melihat pola tersebut sebagai satu kesatuan. Hal ini terlihat ketika S1 menjelaskan informasi yang diketahui dalam soal, S1 menjelaskan dengan memisahkan ruas kanan dan ruas kiri. Sehingga saat membuat konjektur pola ke-n, S1 hanya menuliskan satu ruas saja. S1 dapat memperbaiki konjektur yang salah tetapi tidak dapat mengatasi stuck yang terjadi. Stuck terjadi pada saat aspek maybe. Dalam proses penyelesaian yang dilakukan S1, terdapat conjecturing, convincing, serta generalizing.

Subjek field dependent perempuan secara garis besar mirip dengan yang dilakukan S1 yaitu memenuhi aspek know dan want dalam fase entry, aspek try dan maybe pada fase attack dan aspek check, reflect, dan extend dalam fase review. Ketika memulai fase attack, S2 masih tidak mempunyai rencana penyelesaian yang jelas. S2 masih mencoba beberapa cara penyelesaian yang lebih efektif hingga mendapatkan cara penyelesaian yang benar dan efektif. S2 masih tidak mempunyai keyakinan dalam identifikasi pola pada saat harus membuat konjektur pola ke-3 sehingga S2 hanya menduplikasi pada pembuktian pola ke-2 yang menuntunnya menemukan pola ke-3. S2 juga mengalami kesalahan pada saat membuat konjektur pola ke-n tetapi saat melakukan aspek reflect S2 dapat memperbaikinya. Pada dua konjektur tersebut, saat membuktikannya S2 
mengalami stuck dan tidak dapat mengatasinya. Selain mengalami stuck, S2 juga melakukan conjecturing, convincing, dan generalizing. Bagi pendidik dapat menjadi referensi ilmiah dan mengetahui proses berpikir matematis field dependent lebih mendalam. Bagi peneliti selanjutnya dapat meneliti lebih mendalam mengenai perbedaan dan persamaan proses berpikir maematis field dependent serta sejauh mana ketidakmandirian field dependent dalam menyelesaikan masalah.

\section{DAFTAR RUJUKAN}

Ahmadzade, L., \& Shojae, M. (2013). Investigating the Relationship between Cognitive Style (Filed Dependence/Independence) and Academic Achievement in Male and Female Students of Behbahan Islamic Azad University. Journal of Life Science and Biomedicine, 3(3), 245-249.

Mohammad, M. (2017). Proses Pemecahan Masalah Matematika Berdasarkan Langkah Polya Ditinjau dari Gaya Kognitif dan Gender. Tesis tidak diterbitkan. Universitas Negeri Malang, Malang.

Altun, A., \& Cakan, M. (2006). Undergraduate Students' Academic Achievement, Field Dependent/Independent Cognitive Styles and Attitude Toward Computers. Educational Technology and Society, 9(1), 289-297.

Azari, S., Radmehr, F., Mohajer, M., \& Alamolhodaei, H. (2013). A Study on the Relationship Between Students Cognitive Style and Mathematical Word and Procedural Problem Solving While Controlling for Students' Intelligent Quotient and Math Anxiety. European Journal of Child Development, 1(2), 59-73.

Creswell, J. W. (2012). Educational Research (Fourth Ed). Boston: Pearson.

Delima, N. (2017). a Relationship Between Problem Solving Ability and Students' Mathematical Thinking. Infinity Journal, 6(1), 22. https://doi.org/10.22460/infinity.v6i1.231

Ersoy, E., \& Guner, P. (2015). The Place of Problem Solving and Mathematical Thinking. The Online Journal of New Horizons in Education, 5(1), 120-130.

Guisande, M. A., Páramo, M. F., Tinajero, C., \& Almeida, L. S. (2007). Field Dependence-Independence (FDI) Cognitive Style: An Analysis of Attentional Functioning. Psicothema, 19(4), 572-577.

Kepner, M. D., \& Neimark, E. D. (1984). Test-Retest Reliability and Differential Patterns of Score Change on the Group Embedded Figures Test. Journal of Personality and Social Psychology, 46(6), 1405-1413. https://doi.org/10.1037/0022-3514.46.6.1405

Naurzalina, D., Karimova, A., Sarkulov, M., Tolegenova, A., \& Zholamanova, Ainura Almurzayeva, B. (2015). Cognitive Style and Gender Differencies in Spatial Abilities. In The European Proceedings of Social \& Behavioural Sciences (pp. 95105). Future Academy. https://doi.org/10.15405/epsbs.2015.01.11

NCTM. (2000). Principle and Standards for School Mathematics. Reston: The National Council of Teacher of Mathematics, Inc.

Sanjaya, A., Johar, R., Ikhsan, M., \& Khairi, L. (2018). Students' Thinking Process in Solving Mathematical Problems Based on the Levels of Mathematical Ability. In The 6th South East Asia Design Reserch International Conference (Vol. 1088). IOP Publishing. https://doi.org/10.1088/1742-6596/1088/1/012116

Sozcu, O. F. (2014). The Relationships Between Cognitive Style of Field Dependence and Learner Variables in E-Learning Instruction. Turkish Online Journal of Distance Education, 15(2), 117-144. https://doi.org/10.17718/tojde.11039

Stacey, K. (2007). What Is Mathematical Thinking and Why Is It Important? Review of Educational Research, 82(3), 330-348. https://doi.org/10.3102/0034654312457429

Sukoriyanto, S., Nusantara, T., Subanji, S., \& Chandra, T. D. (2016). Students' Errors in Solving the Permutation and Combination Problems Based on Problem Solving Steps of Polya. International Education Studies, 9(2), 11. https://doi.org/10.5539/ies.v9n2p11

Wechsler, S. M. (2009). Age and Gender Impact on Thinking and Creating Styles. European Journal of Education and Psychology, 2(1), 37-48. 